Journal of Mathematics Education and Application

Volume 1 Nomor 1, Maret 2021

\title{
Penerapan Model Discovery Learning pada Pembelajaran Garis Singgung Lingkaran untuk Meningkatkan Aktivitas dan Prestasi Belajar Siswa
}

\section{Ahmad Febrian Rusdiansyah ${ }^{1 *}$, Sripatmi ${ }^{2}$, Yunita Septriana Anwar ${ }^{3}$, Nurul Hikmah ${ }^{2}$}

\author{
${ }^{1}$ Mahasiswa Pendidikan Matematika, Universitas Mataram, Mataram \\ ${ }_{2}^{2}$ Pendidikan Matematika, Universitas Mataram, Mataram \\ ${ }^{3}$ Pendidikan Matematika, Universitas Muhammadiyah Mataram, Mataram
}

*Corresponding Author e-mail: afebrianrr@yahoo.com

Received: 27-01-2021; Revised: 24-03-2021; Published: 25-03-2021

\begin{abstract}
The background of this research is the low activity and achievement of students' mathematics learning, one of which is due to the selection of learning models that are less varied. The activities of students are only limited to listening, taking notes, then doing practice questions. Discovery Learning is a learning model that directs students to be able to find concepts through the learning process they do which is expected to increase the activities and learning achievements of students. This type of research is a classroom action research (PTK) which is carried out in two cycles and each cycle contains the stages of action planning, action implementation, observation, and evaluation, as well as a reflection stage. The results showed that there was an increase in the activity and learning achievement of students where the learning activities of students in the first cycle with an average score of 10.51 were categorized as high, while in the second cycle with an average score of 13.67, they were categorized as very high. The average score of the learning evaluation results of students has increased in each cycle, namely in the first cycle the average score of the learning evaluation results was 72.65 with a percentage of $62.07 \%$ completeness and in the second cycle the average score of the learning evaluation results was 79.24 with a percentage of completeness of $86.21 \%$. Based on the achievements obtained, it can be concluded that the Discovery learning model can increase the activity and learning achievement of students in learning tangents to circles.
\end{abstract}

Keywords: Learning Activities; Discovery Learning Model; Learning Achievement

\begin{abstract}
Abstrak
Latar belakang penelitian ini adalah rendahnya aktivitas dan prestasi belajar matematika peserta didik yang salah satunya disebabkan karena pemilihan model pembelajaran yang kurang bervariasi. Kegiatan peserta didik hanya terbatas pada mendengarkan, mencatat, kemudian mengerjakan latihan soal. Discovery Learning sebagai salah satu model pembelajaran yang mengarahkan peserta didik untuk dapat menemukan konsep melalui proses pembelajaran yang dilakoninya yang diharapkan dapat meningkatkan aktivitas dan prestasi belajar peserta didik. Jenis penelitian ini adalah penelitian tindakan kelas (PTK) yang dilaksanakan dalam dua siklus dan tiap siklus memuat tahap perencanaan tindakan, pelaksanaan tindakan, observasi, dan evaluasi, serta tahap refleksi. Hasil penelitian menunjukkan bahwa terjadi peningkatan aktivitas dan prestasi belajar peserta didik dimana aktivitas belajar peserta didik pada siklus I dengan rata-rata skor 10,51 berkategori tinggi, sedangkan pada siklus II dengan rata-rata skor 13,67 berkategori sangat tinggi. Skor rata-rata hasil evaluasi belajar peserta didik mengalami peningkatan pada tiap siklus, yaitu pada siklus I rata-rata skor hasil evaluasi belajar 72,65 dengan persentase ketuntasan $62,07 \%$ dan pada siklus II skor rata-rata hasil evaluasi belajar 79,24 dengan persentase ketuntasan 86,21\%. Berdasarkan pencapaian yang diperoleh, maka dapat disimpulkan bahwa model Discovery learning dapat meningkatkan aktivitas dan prestasi belajar peserta didik pada pembelajaran garis singgung lingkaran.
\end{abstract}

Kata Kunci: Aktivitas Belajar; Model Discovery Learning; Prestasi Belajar 


\section{Cara Mengutip}

Rusdiansyah, A.F., Sripatmi, Anwar, Y.S., \& Hikmah, N. (2021). Penerapan model discovery learning pada pembelajaran garis singgung lingkaran untuk meningkatkan aktivitas dan prestasi belajar siswa. Griya Journal of Mathematics Education and Application, 1(1), 19-28.

\section{PENDAHULUAN}

Berdasarkan Undang-Undang RI Nomor 20 Tahun 2003 tentang Sistem Pendidikan Nasional menyatakan bahwa pendidikan adalah usaha sadar dan terencana untuk mewujudkan suasana belajar dan proses pembelajaran agar peserta didik secara aktif mengembangkan potensi dirinya untuk memiliki kekuatan spiritual keagamaan, pengendalian diri, kepribadian, kecerdasan, akhlak mulia, serta keterampilan yang diperlukan dirinya, masyarakat, bangsa, dan negara. Artinya, pendidikan merupakan salah satu hal penting yang menentukan kemajuan suatu bangsa.

Salah satu mata pelajaran yang ada dalam muatan pendidikan di Indonesia adalah matematika. Matematika merupakan salah satu bidang ilmu yang sangat penting karena banyak persoalan-persoalan dalam kehidupan sehari-hari dapat diselesaikan dengan konsep matematika. Apalagi di era teknologi saat ini banyak informasi yang disampaikan menggunakan bahasa matematika seperti tabel, grafik, diagram, dan lain-lain. Untuk itu mata pelajaran matematika diberikan kepada semua peserta didik mulai dari sekolah dasar untuk membekali mereka dengan kemampuan berpikir logis, analitis, sistematis, kritis, dan kreatif serta kemampuan bekerja sama sehingga prestasi belajar matematika peserta didik di Indonesia semakin berkualitas.

Namun kenyataannya prestasi belajar matematika di Indonesia masih tergolong rendah. Hal ini dapat dilihat dari hasil survei yang dilakukan oleh OECD (Organisation for Economic Co-operation and Development) dengan menggunakan tes PISA. Pada tahun 2015, dari 70 negara yang ikut dievaluasi dalam tes PISA, Indonesia berada pada peringkat 63 untuk kompetensi dasar matematika. Rendahnya prestasi belajar matematika terjadi pula pada peserta didik kelas VIII SMP Negeri 16 Mataram seperti yang ditunjukkan dari hasil ulangan akhir semester ganjil tahun pelajaran 2016/2017 pada Tabel 1 berikut.

Tabel 1. Data Nilai Ulangan Akhir Semester Ganjil kelas VIII SMP Negeri 16 Mataram Tahun Pelajaran 2016/2017

\begin{tabular}{ccccc}
\hline No. & Kelas & Jumlah Peserta Didik & Rata-Rata Nilai & Ketuntasan Klasikal \\
\hline 1 & VIII-A & 30 & 60,00 & $33,33 \%$ \\
2 & VIII-B & 30 & 63,50 & $36,67 \%$ \\
3 & VIII-C & 29 & 62,41 & $34,48 \%$ \\
4 & VIII-D & 27 & 62,96 & $37,04 \%$ \\
5 & VIII-E & 27 & 59,72 & $33,33 \%$ \\
\hline \multicolumn{2}{l}{ (Sumber: Daftar Nilai Guru Matematika Kelas VIII SMP Negeri 16 Mataram) }
\end{tabular}


Dari data Tabel 1 diketahui bahwa kelas VIII-A merupakan salah satu kelas dengan ratarata nilai dan ketuntasan klasikal rendah dimana hanya 10 peserta didik yang memperoleh nilai diatas KKM padahal Kriteria Ketuntasan Minimal (KKM) yang ditetapkan sekolah yaitu 75 dan ketuntasan klasikal masih dibawah 85\%. Beberapa permasalahan yang ditemui pada peserta didik kelas VIII-A secara umum berdasarkan hasil observasi selama kegiatan PPL, antara lain: (1) pemilihan model pembelajaran yang masih berpusat pada guru sehingga kegiatan peserta didik terbatas pada mendengarkan dan mencatat penjelasan materi dari guru kemudian mengerjakan tugas dan latihan soal; (2) peserta didik cenderung pasif serta jarang bertanya kepada guru karena masih merasa malu dalam berpendapat dan takut salah, akibatnya peserta didik lebih sering bertanya kepada teman sekelasnya yang lain dan (3) peserta didik cepat terpengaruh oleh teman sekelasnya jika diajak melakukan hal-hal diluar konteks pembelajaran yang sedang berlangsung.

Walaupun demikian, peserta didik kelas VIII-A masih memiliki potensi yang diketahui berdasarkan pengalaman kegiatan PPL dan dapat dikembangkan agar mereka menjadi lebih aktif dalam proses kegiatan pembelajaran. Potensi tersebut antara lain: (1) peserta didik dapat dilibatkan aktif dalam kegiatan pembelajaran yang bersifat menemukan suatu rumus atau konsep dengan menggunakan lembar kerja atau tugas-tugas kelompok kemudian mempresentasikannya di depan kelas; (2) peserta didik mampu bekerja sama dalam belajar jika diorganisasikan ke dalam kelompok-kelompok kecil; dan (3) peserta didik terlihat antusias ketika dalam pembelajaran menggunakan media pendukung pembelajaran seperti penggunaan aplikasi Powerpoint dan alat peraga atau gambargambar.

Untuk mengatasi permasalahan tersebut diperlukan suatu perubahan dalam model pembelajaran yang mampu memberikan kesempatan kepada peserta didik untuk lebih aktif berpikir dan menemukan sesuatu yang baru dengan menggunakan pengetahuan yang sudah dimilikinya sebelumnya. Salah satunya dengan menerapkan model Discovery Learning. Model Discovery Learning adalah suatu model untuk mengembangkan cara belajar peserta didik aktif dengan menemukan sendiri, menyelidiki sendiri, maka hasil yang diperoleh akan bertahan lama dalam ingatan, tidak mudah dilupakan peserta didik.

Dalam kaitannya dengan materi Garis Singgung Lingkaran, berdasarkan informasi dari guru mata pelajaran matematika kelas VIII diketahui bahwa materi tersebut merupakan salah satu materi yang dianggap sulit oleh peserta didik di semester genap. Peserta didik sering mengalami kesulitan dalam (1) menghitung panjang garis singgung lingkaran karena masih salah dalam menggunakan teorema Pythagoras; dan (2) menghitung panjang garis singgung persekutuan dua lingkaran karena peserta didik seringkali tertukar dalam menggunakan rumus mencari panjang garis singgung persekutuan dalam dan panjang garis singgung persekutuan luar dua lingkaran. Berikut disajikan data nilai rata-rata hasil ulangan harian peserta didik kelas VIII SMP Negeri 16 Mataram tahun pelajaran 2015/2016. 
Tabel 2. Data Nilai Rata-Rata Hasil Ulangan Harian Kelas VIII SMP Negeri 16 Mataram Tahun Pelajaran 2015/2016

\begin{tabular}{clcc}
\hline No. & \multicolumn{1}{c}{ Materi } & Nilai Rata-Rata & Ketuntasan Klasikal \\
\hline 1. & Lingkaran & 70,98 & $59,26 \%$ \\
2. & Garis Singgung Lingkaran & 66,05 & $49,29 \%$ \\
3. & Kubus dan balok & 72,47 & $66,50 \%$ \\
\hline
\end{tabular}

(Sumber: Daftar Nilai Guru Matematika Kelas VIII SMP Negeri 16 Mataram)

Pada Tabel 2 terlihat bahwa materi garis singgung lingkaran merupakan salah satu materi dengan ketuntasan klasikal yang rendah berdasarkan nilai rata-rata hasil ulangan harian pada peserta didik angkatan 2015/2016. Karena adanya kesamaan dalam hal kemampuan intelektual, latar belakang sosial serta gaya belajar pada peserta didik angkatan 2015/2016 dengan peserta didik angkatan 2016/2017 maka terdapat kemungkinan bahwa rendahnya aktivitas dan prestasi belajar peserta didik di kelas VIIIA tahun pelajaran 2016/2017 juga akan terulang pada materi garis singgung lingkaran apabila digunakan model pembelajaran yang sama misalnya masih menggunakan model pembelajaran yang berpusat pada guru.

Model Discovery Learning memberikan ruang kepada peserta didik untuk menemukan sendiri suatu konsep atau prinsip, namun guru tetap berkewajiban membimbing, memberikan instruksi serta mendesain pengalaman belajar bagi peserta didik (Aunurrahman, 2016; Fathurrohman \& Sulistyorini, 2012; Suprijono, 2012). Melalui pembelajaran seperti ini tentunya akan membuat peserta didik lebih aktif dalam kegiatan pembelajaran dalam kelas misalnya dalam materi pembelajaran Garis Singgung Lingkaran karena peserta didik akan dituntun dalam menemukan rumusrumus atau konsep baru dengan menggunakan bantuan lembar kerja peserta didik. Peserta didik akan mampu mengoptimalkan pengetahuan yang sudah dimilikinya lalu dengan menyampaikan ide-ide dan pendapat dalam sebuah diskusi kelompok dan akan membantu peserta didik lebih memahami pengetahuan yang didapatkan setelah berdiskusi serta membuat peserta didik lebih berani dalam bertanya dan berkomunikasi dengan teman dan guru. Dengan keadaan ini diharapkan guru tidak lagi mengalami kesulitan dalam mengajarkan materi Garis Singgung Lingkaran serta dengan lebih aktifnya peserta didik dalam mengikuti pelajaran diharapkan prestasi belajar peserta didik juga meningkat.

\section{METODE}

Jenis penelitian ini adalah penelitian tindakan kelas (Classroom Action Research). Penelitian ini dilaksanakan di SMP Negeri 16 Mataram. Subjek penelitian ini adalah peserta didik kelas VIII-A semester II tahun pelajaran 2016/2017 yang berjumlah 29 orang. Penelitian tindakan kelas ini terdiri dari dua siklus dengan masing-masing siklus melalui tahap perencanaan, pelaksanaan, observasi dan evaluasi, serta refleksi. Faktorfaktor yang diteliti dalam penelitian ini adalah faktor peserta didik yakni aktivitas dan prestasi belajar peserta didik dalam pembelajaran garis singgung lingkaran melalui penerapan model Discovery Learning dan faktor guru yang diteliti adalah kegiatan guru 
selama proses pembelajaran garis singgung lingkaran berlangsung dalam menerapkan model Discovery Learning. Adapun rincian pelaksanaan pembelajarannya adalah pada Tabel 3 sebagai berikut.

Tabel 3. Rincian Materi dan Pertemuan Tiap Siklus

\begin{tabular}{|c|c|c|c|}
\hline Siklus & Pert & Kegiatan Pembelajaran & Waktu \\
\hline \multirow{3}{*}{$\mathrm{I}$} & 1 & $\begin{array}{c}\text { Menemukan pengertian dan sifat-sifat garis singgung } \\
\text { lingkaran serta melukis garis singgung lingkaran yang } \\
\text { melalui satu titik pada lingkaran }\end{array}$ & $2 \times 40$ \\
\hline & 2 & $\begin{array}{c}\text { Melukis garis singgung lingkaran yang melalui satu titik di } \\
\text { luar lingkaran serta menemukan dan menghitung panjang } \\
\text { garis singgung lingkaran }\end{array}$ & $2 \times 40$ \\
\hline & 3 & Evaluasi Siklus I & $2 \times 40$ \\
\hline \multirow{4}{*}{ II } & 1 & $\begin{array}{c}\text { Menemukan rumus dan menghitung panjang garis singgung } \\
\text { persekutuan dalam dua lingkaran }\end{array}$ & $2 \times 40$ \\
\hline & 2 & $\begin{array}{c}\text { Menemukan rumus dan menghitung panjang garis singgung } \\
\text { persekutuan luar dua lingkaran }\end{array}$ & $2 \times 40$ \\
\hline & 3 & Evaluasi Siklus II & $2 \times 40^{\prime}$ \\
\hline & & JUMLAH & $12 \times 40^{\prime}$ \\
\hline
\end{tabular}

Data-data penelitian diambil dengan menggunakan dua instrumen penelitian yaitu: lembar observasi yang digunakan untuk memperoleh data aktivitas belajar peserta didik dan data aktivitas guru serta tes evaluasi belajar untuk mengetahui prestasi belajar peserta didik. Data aktivitas belajar peserta didik dianalisis dengan menggunakan rumus $\mathrm{X}=\sum A_{i}$, dimana $\mathrm{X}$ : skor aktivitas belajar peserta didik; $A_{i}$ : skor indikator aktivitas belajar peserta didik. Untuk menentukan kriteria aktivitas belajar peserta didik digunakan skor standar yang dijabarkan menurut pedoman penilaian Nurkancana dan Sunartana (1990) seperti pada tabel berikut.

Tabel 4. Pedoman Kriteria Aktivitas Belajar Peserta Didik

\begin{tabular}{ccc}
\hline Interval Skor & Interval Skor & Kategori \\
\hline$X \geq \mathrm{MI}+1,5$ SDI & $X \geq 13,5$ & Sangat Tinggi \\
$\mathrm{MI}+0,5 \mathrm{SDI} \leq X<\mathrm{MI}+1,5$ SDI & $10,5 \leq X<13,5$ & Tinggi \\
$\mathrm{MI}-0,5 \mathrm{SDI} \leq X<\mathrm{MI}+0,5$ SDI & $7,5 \leq X<10,5$ & Cukup \\
$\mathrm{MI}-1,5 \mathrm{SDI} \leq X<\mathrm{MI}-0,5$ SDI & $4,5 \leq X<7,5$ & Rendah \\
$X<\mathrm{MI}-1,5$ SDI & $X<4,5$ & Sangat Rendah \\
\hline
\end{tabular}

Data aktivitas mengajar guru dianalisis dengan menggunakan rumus $Y=\sum B_{i}$, dimana $Y$ : skor aktivitas guru; $B_{i}$ : skor indikator aktivitas guru. Untuk menentukan kriteria aktivitas mengajar guru digunakan skor standar yang dijabarkan menurut pedoman penilaian Nurkancana dan Sunartana (1990) seperti pada tabel berikut. 
Tabel 5. Pedoman Kriteria Aktivitas Guru

\begin{tabular}{ccc}
\hline Interval Skor & Interval Skor & Kategori \\
\hline$Y \geq \mathrm{MI}+1,5$ SDI & $Y \geq 13,5$ & Sangat Baik \\
$\mathrm{MI}+0,5 \mathrm{SDI} \leq Y<\mathrm{MI}+1,5$ SDI & $10,5 \leq Y<13,5$ & Baik \\
$\mathrm{MI}-0,5 \mathrm{SDI} \leq Y<\mathrm{MI}+0,5$ SDI & $7,5 \leq Y<10,5$ & Cukup \\
$\mathrm{MI}-1,5 \mathrm{SDI} \leq Y<\mathrm{MI}-0,5$ SDI & $4,5 \leq Y<7,5$ & Kurang \\
$Y<\mathrm{MI}-1,5$ SDI & $Y<4,5$ & Sangat Kurang \\
\hline
\end{tabular}

Data prestasi belajar peserta didik dianalisis secara deskriptif yaitu dengan menentukan rata-rata nilai evaluasi belajar pada masing-masing siklus dengan rumus $\mathrm{M}=\frac{\sum X}{n}$, dimana $\mathrm{M}$ : rata-rata nilai kelas; $\sum X$ : jumlah total nilai peserta didik; $n$ : banyak peserta didik yang mengikuti tes. Untuk menentukan ketuntasan belajar siswa secara klasikal dianalisis dengan menggunakan rumus $K B=\frac{n_{i}}{n} \times 100 \%$ dengan $K B$ : ketuntasan klasikal; $n_{i}$ : banyak peserta didik yang memperoleh nilai $\geq 75 ; n$ : banyak peserta didik yang mengikuti tes (Sudjana, 2005).

Penelitian ini dikatakan berhasil apabila aktivitas belajar peserta didik minimal berkategori tinggi di akhir siklus II dan nilai rata-rata hasil evaluasi belajar peserta didik lebih dari atau sama dengan 75 serta tercapainya ketuntasan belajar secara klasikal minimal $85 \%$ setelah diterapkan model Discovery Learning.

\section{HASIL DAN PEMBAHASAN}

Secara keseluruhan, hasil yang diperoleh dalam penelitian ini dapat dilihat pada tabel ringkasan hasil penelitian berikut.

Tabel 6. Ringkasan hasil penelitian

\begin{tabular}{cccccc}
\hline \multirow{2}{*}{ Siklus } & Pert & \multicolumn{2}{c}{ Aktivitas Belajar } & Rata-Rata & Ketuntasan \\
\cline { 3 - 4 } & & Skor Aktivitas & Kategori & Hasil Belajar & Klasikal \\
\hline \multirow{2}{*}{ I } & 1 & 10,01 & Cukup & 72,65 & $62,07 \%$ \\
& 2 & 11,01 & Tinggi & & \\
II & 1 & 13,33 & Tinggi & 79,24 & $86,21 \%$ \\
\hline
\end{tabular}

Berdasarkan Tabel 6 di atas terlihat bahwa pada siklus I pertemuan 1 skor aktivitas peserta didik adalah 10,01 dengan kategori cukup tinggi, sedangkan pada pertemuan 2 skor aktivitas peserta didik mengalami peningkatan menjadi 11,01 dengan kategori tinggi. Hal ini menunjukkan bahwa aktivitas peserta didik pada siklus I mengalami peningkatan dari pertemuan 1 ke pertemuan 2. Pada pertemuan 1 siklus I aktivitas peserta didik dalam tahap merumuskan hipotesis, kegiatan penemuan, dan partisipasi dalam kegiatan penutup masih kurang aktif. Namun pada pertemuan 2 siklus I terjadi peningkatan terhadap kekurangan-kekurangan yang terdapat pada pertemuan 1 diantaranya tiap kelompok sudah dapat merumuskan hipotesis sesuai dengan stimulus yang diberikan oleh guru, peserta didik sudah berani bertanya kepada guru mengenai 
hal yang belum dimengerti di LKPD dan sudah cukup banyak peserta didik yang mengacungkan tangan untuk mencoba menyampaikan kesimpulan hasil pembelajaran.

Pada evaluasi siklus I diperoleh hasil yakni nilai rata-rata sebesar 72,65 dengan nilai tertinggi 96 dan nilai terendah 33 serta terdapat 11 orang peserta didik yang tidak tuntas dan ketuntasan klasikal sebesar 62,07 \%. Hal ini menunjukkan bahwa prestasi belajar peserta didik belum mampu mencapai indikator keberhasilan yang telah ditetapkan yaitu ketuntasan belajar peserta didik dengan persentase lebih dari atau sama dengan 85\%. Dari hasil analisis evaluasi siklus 1 peserta didik paling banyak mengalami kesalahan dalam hal melukis garis singgung lingkaran yang melalui satu titik pada lingkaran dan yang melalui satu titik di luar lingkaran karena secara teknis peserta didik banyak yang tidak membawa jangka dan busur derajat. Selain itu masih ada peserta didik yang tidak hadir dalam kegiatan pembelajaran sehingga hal tersebut menjadi indikasi peserta didik tidak tuntas.

Kekurangan-kekurangan yang terjadi pada siklus I diperbaiki sebagai berikut diantaranya guru tetap mengingatkan kepada peserta didik untuk selalu membawa kelengkapan pembelajaran dan mengingatkan untuk langsung duduk bersama kelompoknya ketika menjelang pelajaran matematika akan dimulai, guru tetap menginstruksikan kepada peserta didik untuk membagi tugas dalam diskusi kelompok sehingga tidak ada peserta didik yang tidak membantu dalam menyelesaikan LKPD, membuatkan media pembelajaran bagi peserta didik untuk mempresentasikan hasil diskusinya agar tidak memakan waktu lama. Selain itu, guru mengajukan beberapa pertanyaan misalnya mengenai hasil presentasi atau materi pembelajaran untuk mendorong peserta didik berani dalam berpendapat dan menyimpulkan hasil pembelajaran. Guru juga tetap memberikan PR kepada peserta didik sebagai latihan dirumah.

Perbaikan-perbaikan tersebut diimplementasikan pada siklus II diperoleh hasil seperti peserta didik sudah membawa kelengkapan pembelajaran, interaksi antar anggota dalam kelompok berjalan cukup baik, dan sudah ada pembagian kerja yang jelas saat kegiatan penemuan dalam menyelesaikan LKPD. Peserta didik sudah cukup baik dalam memperhatikan jalannya presentasi dan sudah berani dalam berpendapat dalam memberikan tanggapan atau pertanyaan terkait hasil presentasi kelompok dan dalam menyimpulkan materi yang sudah dibahas di akhir pelajaran. Namun, pada siklus II ini terdapat beberapa kekurangan diantaranya keadaan kelas ketika guru masuk masih belum tertib dan masih ada peserta didik yang sempat berkeliaran di dalam kelas ketika mengerjakan soal latihan individu. Akan tetapi, kekurangan yang ada di siklus II ini dapat diminimalisir oleh guru sehingga tidak mengurangi keoptimalan penerapan model Discovery Learning karena tahapan-tahapan dari model Discovery Learning pada siklus II ini sudah diterapkan dengan optimal dan kekurangan-kekurangan yang ada pada siklus I juga telah diperbaiki pada siklus II ini.

Hasil yang diperoleh pada siklus II yang terlihat pada Tabel 6 menunjukkan rata-rata skor aktivitas belajar peserta didik sebesar 13,67 berkategori sangat tinggi. Dari sisi prestasi belajar, dari Tabel 6 menunjukkan terjadi peningkatan prestasi belajar peserta 
didik. Hal ini ditunjukkan dengan meningkatnya persentase ketuntasan klasikal dari siklus I sebesar $62,07 \%$ menjadi $86,21 \%$ pada siklus II. Artinya pada siklus I dari 29 peserta didik yang mengikuti tes evaluasi, jumlah peserta didik yang tuntas adalah 18 orang dan pada siklus II, jumlah peserta didik yang tuntas meningkat menjadi 25 orang. Dengan kata lain aktivitas dan prestasi belajar peserta didik pada siklus II telah mencapai indikator keberhasilan. Berdasarkan data-data yang ada dapat digunakan untuk mengambil kesimpulan, untuk itu penelitian ini dihentikan.

Hasil yang diperoleh pada siklus I dan II dikarenakan model Discovery Learning mengembangkan cara belajar peserta didik dimana melalui tahapan-tahapannya sehingga peserta didik aktif menyelidiki teori atau rumus dalam usahanya menemukan solusi permasalahan yang diberikan (Hosnan, 2014; Kosasih, 2015; Nurdin \& Adriantoni, 2016). Sehingga hasil penemuan yang diperoleh bertahan lama dalam ingatan peserta didik. Ini juga menyebabkan peserta didik mampu menyelesaikan soalsoal evaluasi di tiap siklus. Dengan berpartisipasi aktif dalam pembelajaran, pengetahuan yang dimiliki peserta didik akan berkembang dengan lebih baik yang pada akhirnya diharapkan mampu meningkatkan prestasi belajar peserta didik. Tercapainya indikator keberhasilan pada siklus II ini menunjukkan bahwa aktivitas dan prestasi belajar peserta didik dapat ditingkatkan melalui penerapan model Discovery Learning. Lebih lanjut, peningkatan yang terjadi tersebut tidak terlepas dari poin penting model Discovery Learning, yaitu menemukan. Sesuai dengan namanya, model ini mengarahkan peserta didik untuk dapat menemukan sesuatu melalui proses pembelajaran yang dilakoninya. Dengan belajar menemukan, peserta didik akan memahami konsep-konsep dasar dan ide-ide dengan lebih baik. Sehingga hasil belajar dengan cara pembelajaran seperti ini akan lebih mudah diingat dan mudah ditransfer untuk memecahkan masalah. Ini sesuai dengan salah satu kelebihan model Discovery Learning yang yaitu peserta didik memperoleh pengetahuan yang bersifat sangat pribadi atau individual sehingga dapat kokoh/mendalam tertinggal dalam jiwa peserta didik.

Dengan demikian, berdasarkan pembahasan maka penerapan model Discovery Learning dapat meningkatkan aktivitas dan prestasi belajar peserta didik pada pembelajaran garis singgung lingkaran di kelas VIII-A SMP Negeri 16 Mataram tahun pelajaran $2016 / 2017$.

\section{PENUTUP}

\subsection{Kesimpulan}

Dari penelitian yang telah dilakukan, dapat ditarik kesimpulan sebagai berikut:

1. Langkah-langkah penerapan model Discovery Learning sehingga dapat meningkatkan aktivitas dan prestasi belajar peserta didik pada pembelajaran garis singgung lingkaran di kelas VIII-A SMP Negeri 16 Mataram tahun pelajaran 2016/2017 adalah sebagai berikut:

a. Tahap Stimulation, dimana pada tahap ini guru memberikan penjelasan dan melontarkan pertanyaan tentang konsep awal yang akan dikembangkan pada 
saat pembelajaran dan berkaitan dengan permasalahan dalam kehidupan nyata dengan menggunakan media.

b. Tahap Problem Statement, dimana pada tahap ini guru memberikan kesempatan kepada seluruh peserta didik untuk berdiskusi dengan kelompoknya untuk mengidentifikasi dan merumuskan jawaban sementara (hipotesis) berdasarkan stimulus yang telah diberikan.

c. Tahap Data Collection, dimana pada tahap ini guru membagikan LKPD untuk tiap kelompok dan menjelaskan tugas serta batasan waktu kegiatan. Tahap ini memberikan kesempatan peserta didik untuk berdiskusi, membaca buku, melakukan uji coba dan mengumpulkan data yang relevan.

d. Tahap Data Processing, dimana pada tahap ini peserta didik dalam tiap kelompok mengolah, menafsirkan dan mengecek terkait data-data yang telah dikumpulkan.

e. Tahap Verification, dimana pada tahap ini tiap kelompok melakukan pemeriksaan untuk membuktikan benar atau tidaknya jawaban sementara (hipotesis) yang telah ditetapkan sebelumnya terkait dengan data-data yang telah diolah.

f. Tahap Generalization, dimana pada tahap ini peserta didik berdiskusi untuk membuat kesimpulan dan menuliskannya pada LKPD.

2. Penerapan model Discovery Learning secara optimal dapat meningkatkan aktivitas dan prestasi belajar peserta didik pada pembelajaran garis singgung lingkaran di kelas VIII-A SMP Negeri 16 Mataram tahun pelajaran 2016/2017. Hal ini terlihat dari peningkatan skor aktivitas belajar peserta didik pada siklus I untuk tiap pertemuan adalah 10,01 dan 11,01 dengan masing-masing berkategori cukup tinggi dan tinggi. Sedangkan skor aktivitas belajar peserta didik pada siklus II untuk tiap pertemuan adalah 13,33 dan 14,00 dengan masing-masing berkategori tinggi dan sangat tinggi. Rata-rata nilai hasil evaluasi belajar peserta didik pada siklus I dan II masing-masing adalah 72,65 dan 79,24 dengan ketuntasan klasikal pada siklus I dan II masing-masing adalah $62,07 \%$ dan $86,21 \%$.

\subsection{Saran}

Dari penelitian yang telah dilakukan, adapun saran-saran yang dapat peneliti sampaikan adalah sebagai berikut:

1. Bagi guru matematika di kelas VIII-A SMP Negeri 16 Mataram diharapkan dapat menerapkan model Discovery Learning sebagai alternatif pembelajaran di dalam kelas untuk meningkatkan aktivitas dan prestasi belajar siswa.

2. Bagi peserta didik diharapkan dapat lebih aktif dan termotivasi untuk membangun pemahaman konsepnya secara mandiri melalui kerjasama kelompok sehingga dapat mencapai prestasi belajar yang memuaskan.

3. Bagi peneliti selanjutnya yang menerapkan model Discovery Learning agar pembelajaran lebih dioptimalkan dengan memperhatikan langkah-langkah kegiatan pembelajaran yang dapat mengacu pada kekurangan dan langkah-langkah perbaikannya yang akan dilakukan dalam penelitian ini. 


\section{REFERENSI}

Aunurrahman. (2016). Belajar dan Pembelajaran. Bandung: Alfabeta.

Fathurrohman, M., \& Sulistyorini. (2012). Belajar dan Pembelajaran. Yogyakarta: Teras.

Hamalik, O. (2013). Proses Belajar Mengajar. Jakarta: Bumi Aksara.

Hosnan. (2014). Pendekatan Saintifik dan Kontekstual dalam Pembelajaran Abad 21 Kunci Sukses Implementasi Kurikulum 2013. Jakarta: Ghalia Indonesia.

Komara, E. (2014). Belajar dan Pembelajaran Interaktif. Bandung: Refika Aditama.

Kosasih, E. (2015). Belajar dan Pembelajaran Implementasi Kurikulum 2013. Bandung: Yrama Widya.

Nurdin, S., \& Adriantoni. (2016). Kurikulum dan Pembelajaran. Jakarta: Rajawali Press.

Nurkancana, W., \& Sunartana. (1990). Evaluasi Hasil Belajar. Surabaya: Usaha Nasional.

Slameto. (2013). Belajar dan Faktor-Faktor yang Mempengaruhinya. Jakarta: PT Rineka Cipta.

Sudjana, N. (2005). Metoda Statistika. Bandung: Tarsito.

Suprijono, A. (2012). Cooperative Learning Teori dan Aplikasi PAIKEM. Yogyakarta: Pustaka Belajar.

Suyono \& Hariyanto. (2014). Belajar dan Pembelajaran. Bandung: Remaja Rosdakarya.

Taufik, I. (2010). Kamus Praktis Bahasa Indonesia. Jakarta: Ganeca Exact. 